\title{
Distributed Generation from Renewable Energy Sources: Ending Energy Poverty Across the World
}

\begin{abstract}
Mario Pagliaro, ${ }^{[\mathrm{a}]}$ Francesco Meneguzzo ${ }^{[\mathrm{b}]}$
Abstract: Following an updated outlook of global energy production and utilization, we show through selected examples from both developing and developed countries how distributed generation from renewable energy sources, and from solar energy in particular, is the key solution to ending energy poverty across the world. Guidelines aimed at policy makers suggest a systems view of energy that will be instrumental in guiding the transition from fossil fuels to combustion-free renewable energy for all energy end uses.
\end{abstract}

Keywords: energy poverty; primary energy; renewable energy; distributed generation; energy storage

\section{Introduction}

The role played by energy in driving economic growth is generally larger than conventionally assumed [1]. This might suggest to focus efforts and resources on improving energy efficiency to promote general economic growth. Yet, as first understood by Jevons as early as of 1885 , this could well eventually result in higher overall energy consumption in an unwanted economy-wide rebound effect [2,1]. Indeed, if a fraction $1 / n$ of the population starts saving primary energy, then the price of primary energy decreases, enabling the remaining $(n-1) / n$ fraction of the population to purchase higher amounts of primary energy, eventually restoring or even worsening the overall balance of energy consumption.

If, instead, the current and future energy needs of the same the $1 / n$ population fraction are met by renewable energy, this fraction will not pay for its energy because there is no "fuel" cost to bear, while the remaining $(n-1) / n$ fraction will continue to use conventional energy sources.

Now, however, the example of the $1 / n$ fraction of the population consuming energy at little or no cost while retaining the original wellbeing, will lead the remaining part of the population to progressively follow the same path, which is exactly what is currently taking place across the world, following the global solar energy boom started in the early 2000s [3].

[a] Dr. M. Pagliaro

Istituto per lo Studio dei Materiali Nanostrutturati, CNR

via U. La Malfa 153

90146 Palermo (Italy)

E-mail: mario.pagliaro@cnr.it

Web: www.qualitas1998.net

[b] Dr. F. Meneguzzo

Istituto per la Bioeconomia, CNR

via Madonna del Piano 10

50019 Sesto Fiorentino FI (Italy)

E-mail: francesco.meneguzzo@cnr.it
On the other hand, energy saving efforts such as buying highly insulating windows are often hampered by the lack of sufficient financial resources, with the very same lack of money originating from the delay in adopting energy self-generation from renewable energy sources.

The latter situation, for which people in developed countries cannot adequately heat, cool or acquire necessary energy services for their homes defines energy poverty in high-income countries; whereas in developing countries energy poverty generally often translates into not having access to electricity and to all electricity-enabled technologies including lighting.

Research on energy poverty is flourishing. As put it by Galvin, in developed countries three main factors determine domestic energy poverty: low income, energy-inefficiency; and high fuel prices [4]. The condition of the over 1 billion people across the world still missing access to electricity shows evidence that energy poverty is a context-based conceptual construct embedded within the specific social, economic and cultural conditions which define the energy consumption pattern [5].

The path to restoring economic growth in most world's countries, in brief, goes through mass scale adoption of renewable energy in place of oil, whose energy return on investment (EROI) has dramatically decreased from the beginning of the oil era in the early 1900 s, and has continued to do so going from about 30 in 2000 to 17 in 2013 [6].

From a global viewpoint, the rapidly declining oil EROI coupled to rapid global population growth, creates the conditions for energy poverty. We have shown in 2016 that growth in energy demand is driven by the concomitant growth in global population and social and economic activity (i.e., wealth, or GDP) [7]. Yet, whereas relationship between total energy consumption and population is linear, that between global wealth and global population is a power function of the global population [7].

According to the latter equation, if global population will keep growing along the current trajectory, the 800 million people that will add to the global population in 2025 will need about $1,700,000$ ktoe (kilotonne of oil equivalent) of energy over the 2016 level. Even to keep the oil fraction in the energy mix at the 2016 level $(33 \%)$, this translates into more than 11 million extraoil barrels per day (b/d) [7].

The end of energy poverty, we argument in this study, inevitably goes through mass adoption of distributed energy generation from renewable energy sources, and sunlight, wind and water in particular.

Following an updated outlook of global energy production and utilization, we show through selected examples how this is currently taking place across the world in both developing and developed countries. Guidelines aimed at policy makers at the end of the study suggest a systems view of energy that will be 
instrumental in guiding the transition from fossil fuels to combustion-free renewable energy for all energy end uses.

\section{Primary energy supply}

Table 1 shows the global primary energy supply by source in 1990 and in 2017 [8]. Oil is still the dominant energy source, though its increase was limited to $37 \%$, followed by coal $(+70 \%)$, and natural gas $(+87 \%)$. The energy obtained burning biofue and urban waste, grown by $47 \%$, is almost twice higher than nuclear power, which in almost two decades experienced the lowest growth rate $(+30 \%)$ amid all energy sources.

Table 1. Total primary energy supply by source, world 1990 and $2017^{\mathrm{a}}$

\begin{tabular}{l|l|l} 
Energy source & $\begin{array}{l}\text { Energy amount } \\
\text { (ktoe) in 1990 }\end{array}$ & $\begin{array}{l}\text { Energy amount (ktoe) } \\
\text { in } 2017\end{array}$ \\
\hline Coal & $2,220,466$ & $3,789,934$ \\
\hline Natural gas & $1,663,608$ & $3,106,799$ \\
\hline Nuclear & 525,520 & 687,481 \\
\hline Hydro & 184,102 & 351,029 \\
\hline Wind, solar & 36,560 & 256,830 \\
\hline Biofuels and waste & 902,367 & $1,329,064$ \\
\hline Oil & $\underline{3,232,737}$ & $\mathbf{4 , 4 4 9 , 4 9 9}$ \\
\hline Total & $\mathbf{8 , 7 6 5 , 3 6 0}$ & $\mathbf{1 3 , 9 7 0 , 6 3 6}$ \\
\hline
\end{tabular}

${ }^{a}$ Source: International Energy Agency, 2019

The amount of hydroelectric energy almost doubled (+91\%), whereas that of wind and solar photovoltaic energy increased more than seven fold $(+700 \%)$.

Overall, the share of water, wind and sun energy in 2017 amounted to $4.35 \%$ of the global energy supply. In 1990 the latter share was $2.52 \%$. However, the uptake of solar and wind power has been largely non-homogeneous, with China and Germany hosting a far higher installed renewable power per capita generation capacity.

It is therefore relevant to study the impact of such huge and rapid uptake of renewable energy sources on fossil fuel consumption in China (and in India).

\section{The paradigmatic case of China}

By the end of 2018, China had installed $729 \mathrm{GW}$ of renewable energy capacity out of $1900 \mathrm{GW}$ total installed capacity (Table 2) [9]. In 2018 renewable energy accounted for $26.7 \%$ (1868 TWh) of total electricity (6994 TWh) generated during the year.

Table 2. Power installed capacity in China and energy generation by source in $2018^{\mathrm{a}}$

\begin{tabular}{lll} 
Power source & $\begin{array}{l}\text { Total installed } \\
\text { capacity (GW) and } \\
\text { year on year } \\
\text { increase }(\%)\end{array}$ & $\begin{array}{l}\text { Electricity generation } \\
\text { (TWh) and year on } \\
\text { year increase }(\%)\end{array}$ \\
\hline Thermal & $1126(+2.8 \%)$ & $4833(+7.8 \%)$ \\
\hline Nuclear & $45(+24.2 \%)$ & $294(+18.6 \%)$ \\
\hline Hydro & $352(+2.5 \%)$ & $1233(+3.2 \%)$ \\
\hline Wind & $184(+12.4 \%)$ & $366(+20.2 \%)$ \\
\hline Solar & $175(+33.9 \%)$ & $178(+50.8 \%)$ \\
\hline Biomass & $18(+20.7 \%)$ & $91(+14 \%)$ \\
\hline Total & 1900 & 6994
\end{tabular}

aSource: China Electricity Council, 2019.

For comparison, in 200781 percent of the electricity in China was generated burning coal, whereas in 2018 coal accounted for only 59 percent of China's overall energy consumption, regardless of a 8.5 percent rise in electricity generation [9].

Discussing the case of China is relevant for all world's countries because China has achieved goals in new energy technology adoption that other countries will reach in forthcoming years. The Asian country, for example, hosted 401,000 public charging stations for BEVs as of May 2019 [10], when the number of charging stations in the USA or in Russia amounted, respectively, to 20,000 and 400 . Three major outcomes emerge from the ongoing renewable energy uptake in the Asian country.

The first is that coal-fired thermoelectric plants are increasingly pushed out of the market due to the low number of hours in which they actually operate. In China renewable electricity is granted priority in grid access. The outcome has been that $47 \%$ of China's coal-power companies recorded financial losses in January-August 2018, with the others recording limited (1.1\%) profitability [11].

The second is that the profitability of all thermal plants will now be eroded by the newly achieved competitiveness of PV energy generation. Indeed, the first batch of 250 subsidy-free grid-parity wind and solar projects, with a total capacity of nearly $21 \mathrm{GW}$ (in 16 China's provinces) was approved on May 2019 [11].

The third outcome of the rapid industrial progress with new energy technology occurring in China since about a decade, is that battery electric vehicles (BEVs) are starting to impact oil consumption at a significant level. We remind that about $50 \%$ of oil consumption in the world is related to transportation, and $40 \%$ by road transportation [12]. 
Recent estimates point to a lost cumulative demand since 2011 due to the adoption of BEVs of $352,000 \mathrm{~b} / \mathrm{d}$ (the oil consumption of Portugal) [13].

With Li-ion battery production due to rise more than fourfold between 2018 (when it amounted to $294 \mathrm{GWh}$ ) and 2023 (1235 GWh expected [14]), estimates for which by 2040 electric vehicles could displace 7.3 million b/d of oil demand [15], would reveal soon conservative. Indeed, the same consultancy one year later almost doubled the estimate of BEV impact on road gasoline and diesel fuel demand at 13.7 million barrels per day by 2040 [16].

Important benefits of BEVs extend to renewable energy generation. Quantifying the benefits on the power price formed in the day-ahead power market, we have quantified in 2015 the synergistic and beneficial effects on the national energy bill provided by the concomitant expansion of BEV uptake and growth of renewable energy generation, particularly of solar PV [17]. "Although results are derived taking into consideration Italy's power market", we wrote, "results are of relevance also to other industrialized countries" [17].

This has subsequently been the case of China where in 2018, the country reduced wind power curtailment to $7 \%(27.7 \mathrm{TWh}$, a five-percentage point improvement versus 2017) and solar power curtailment to $3 \%$ (5.49 TWh, 2.8 percentage points less than in 2017) [9], also thanks to more several million BEVs absorbing power from the grid at different hours of the day.

\section{World's countries following China's path}

Now that PV modules sell at less than $\$ 0.3 / \mathrm{W}$ and lithium battery packs at less than $\$ 100 / \mathrm{kWh}$, other countries will follow China's path in adopting renewable energy generation and electric vehicles on mass scale. Producing energy from water, wind and sun, and then using said electricity to power electric vehicles dramatically reduces oil and natural gas imports vastly improving national security and the foreign trade balance.

Indeed, the technology is finally being uptaken on multi GW scale by countries such as Egypt, Algeria, Morocco, Jordan, United Arab Emirates, Mexico, Chile, Saudi Arabia and so on where the large-scale uptake of solar energy lagged behind [18].

Chiefly installed in the course of five years only (2015-2019), India hosted $33.8 \mathrm{GW}$ of installed PV power by September 30, 2019 (4 GW of which were from rooftop solar systems) [19]. Out of $356 \mathrm{GW}$ total installed power capacity by March 2019 (Table 3 ), renewable energy sources in India already accounted for 21.8 percent $(77.64 \mathrm{GW})$ [20].

Almost all India's installed PV power was deployed thanks to public tenders for large-scale solar projects with ever decreasing price for the solar electricity purchased by the government through power purchase agreements. Indeed, the government's initial target of $20 \mathrm{GW}$ capacity for 2022, was achieved already in January 2018.
With $36.625 \mathrm{GW}$ of wind power, India is the fourth-largest wind power producer in the world, and hosts in Rajasthan the Bhadla Solar Park, shortly to become with a final capacity of $2.255 \mathrm{GW}$, the world's largest solar power plant.

Table 3. Power installed capacity in India as of March $2019^{a}$

\begin{tabular}{l|l} 
Power source & $\begin{array}{l}\text { Total installed } \\
\text { capacity (GW) and Year on } \\
\text { year increase (\%) }\end{array}$ \\
Coal & $200.7(+1.9 \%)$ \\
\hline Gas & $24.93(+0.1 \%)$ \\
\hline Diesel & $0.63(-24 \%)$ \\
\hline Nuclear & $6.78(0 \%)$ \\
\hline Hydro & $45.39(-0.02 \%)$ \\
\hline Solar & $28.18(+30.15 \%)$ \\
\hline Wind & $35.625(+4.6 \%)$ \\
\hline Biomass & $9.104(+4.64 \%)$ \\
\hline Small hydro & $4.593(+2.4 \%)$ \\
\hline Waste-to-energy & $0.138(0 \%)$ \\
\hline Total & $\mathbf{3 5 6 . 0 7 ( + 3 . 5 5 \% )}$
\end{tabular}

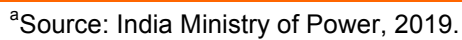

The case of the latter solar park is relevant because it shows evidence of today's ultralow cost PV power generated by utilityscale solar parks. Construction of the solar park took place in four separate auctions. In late 2017, the Bhadla Phase III 500 MW auction ended with record low tariffs of INR 2.44 (\$0.037) per kWh to develop $200 \mathrm{MW}$, and another company winning a bid to develop another $300 \mathrm{MW}$ of grid-connected solar power with a tariff of INR 2.45 (\$0.038) [21].

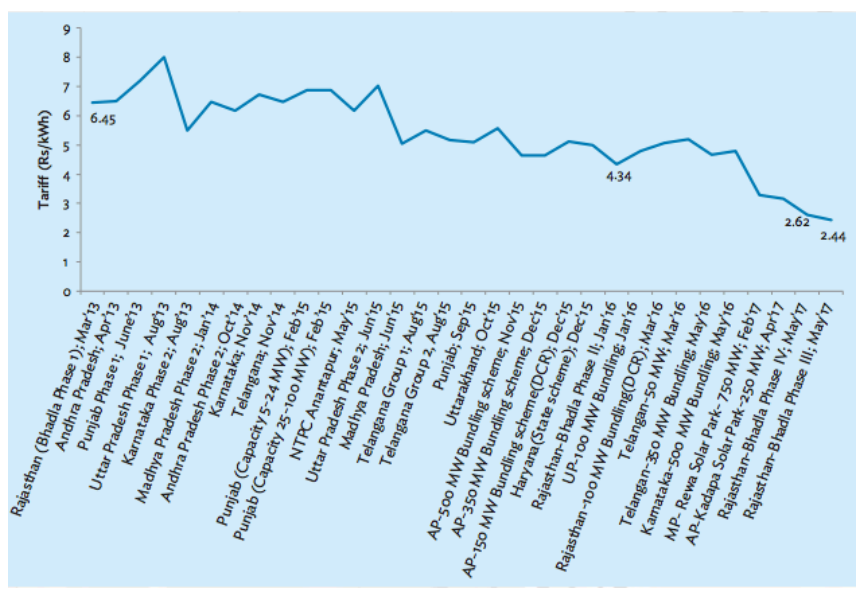

Figure 1. PV electricity tariffs in power purchase agreements signed with India's government since the Bhadla Solar Park Phase I bidding. Rs = Indian rupees. [Image courtesy of Asian Development Bank, reproduced from Ref.21, with kind permission].

Figure 1 shows that the tariff paid by India's government through its Solar Energy Corporation of India has gone in a few years from 8 to 2.44 INR/kWh [21]. 


\section{Ending energy poverty across the world}

After decades of limited progress, distributed generation via domestic PV on mass scale has finally started to improve livelihoods and to drive social development and economic growth across the world. Selected recent examples illustrate how this is happening in both developing and developed countries.

In Bangladesh, 5.5 million solar home systems installed between 2003 and 2018 provide electricity to 20 million people, namely more than $12 \%$ of the population, with the country aiming to install another 500,000 systems by 2021 [22].

Similarly, in slightly more than three years starting in 2016, India's government has installed 135,079 solar LED (light emitting diode) street lights in various part of the immense country [23a]. According to phase III of the same plan (Atal Jyoti Yojna) to illuminate dark regions through solar street lights, a total of 3,00,000 solar street lights will be installed across India, starting from north eastern area and from islands devoid of grid connectivity [23b].

In Sub-Saharan (Tropical) Africa, where close to 700 million people do not have access to electricity, today's low cost PV solar modules coupled to low cost LED lights and Li-ion batteries is bringing electricity to thousands of people each day. For example, a Nairobi-based company after acquiring 600,000 customers across Kenya, Tanzania and Uganda in seven years only (2012-2019), in early 2019 was found to affordably sell different off-grid domestic solar power kits to 500 new homes every day [24].

Showing evidence of how today's ultralow cost of solar energy and energy storage technologies allow low-income families in Africa's rural areas to access electric lighting, mobile phone recharging, radio listening (and now even TV watching), one such kit consisting 2 small PV modules (8 W), a 6.4 Ah Li-ion battery, two LED lights (one bulb and one strip), 2 mobile phone charge cables, one rechargeable FM/USB radio, one rechargeable torch and their charge cable in early 2020 was sold in change of an initial deposit of 2499 Kenyan shelling (ksh, equivalent of $\$ 24.90$ ), with a daily payment of $50 \mathrm{ksh}(\$ 0.5)$ for 410 days [25]. The payment system makes use of the customer mobile phones.

Similar findings hold true for developing and developed regions of the world, with results now being routinely reported in the scholarly literature.

In metropolitan Seoul, in 2016 the South Korea's government entirely covered the installation cost ( $\$ 450$ of a simple PV system comprised of a single $260 \mathrm{~W}$ module equipped with a micro-inverter and a meter installed in the veranda of several low-income households living in public rental apartments [26].

The electricity bill of one representative user for one year (Apr 2018-Mar 2019) shows that real energy production (264.7 kWh) was higher than the average production expected $(243.4$
$\mathrm{kWh} /$ year), with a reduction in the energy bill of about $20 \%$ (from 247,810 KRW to $200,120 \mathrm{KRW}$ ) [26].

Such an achievement was possible with a single solar module with a rated power of $260 \mathrm{~W}$. Today's 60 cell, $21.4 \%$ efficient PV modules in monocrystalline silicon manufactured in South Korea by one of the two country's leading electronics manufacturer have a nominal power of $370 \mathrm{~W}$ [27].

In China's rural Qinghai-Tibet region, the highest plateau in the world with an altitude between $3000 \mathrm{~m}$ and $5000 \mathrm{~m}$, it was enough to install two solar air collectors and an electricity-driven heat pump to heat water at the low temperatures $\left(25-30{ }^{\circ} \mathrm{C}\right)$ required for floor radiation heating to entirely replace wood, animal dung and coal traditionally burned by Tibet's residents for heating, vastly improving the livelihood conditions [28].

China's scholars directed the renovation works and field measured the energy consumption and indoor air temperature of the home prior and after renovation. The energy demand of the renovated house was $153.3 \mathrm{kWh} /$ day lower than that of the original home, whereas the average air temperature of the living room and two bedrooms reached $12.8^{\circ} \mathrm{C}, 11.0^{\circ} \mathrm{C}$ and $10.2^{\circ} \mathrm{C}$, namely $8.78^{\circ} \mathrm{C}, 7.61^{\circ} \mathrm{C}$ and $6.82^{\circ} \mathrm{C}$ higher than temperatures of the rooms in the old building [28].

An energy scholar in South Africa calculated the combined unit energy cost of a real solar energy home system capable to provide electricity and purified water over the system 25 year lifespan for a rural home in Uganda. Starting from a local purchase price of a solar PV module of $\$ 0.7987 / \mathrm{W}$ (when buying on June 2016 a 200 W PV module), a solar water purifier (5 L/day capacity), two batteries (105 Ah each), 12 LED bulbs (11 $\mathrm{W}$ each), and a solar water heater $\left(2 \mathrm{~m}^{2}\right.$ collector $)$, the combined unit energy cost was roughly $\$ 0.03$ [29].

"Solar energy usage by rural households in lighting, hygiene water heating and family drinking water" he concluded the subsequent year should be strongly advocated to reduce energy poverty" [29].

\section{Guidelines and conclusions}

Four major guidelines stem from the analysis carried out in this study on how to alleviate and eventually terminate energy poverty across the world via distributed generation from renewable energy sources, and solar energy in particular, including rural regions of developing countries where the electric grid is absent or insufficient to meet the population needs, though European countries impoverished by over two decades of financial austerity [30], and by increasing fuel prices due to privatization of energy services.

First, ending energy poverty should always translate into alleviating poverty in general. This, following the studies of Israel and Jehling [31], requires policy makers and urban energy managers to adopt a systems view of energy, fully integrated in its local socio-economic context so as to avoid, for instance, topdown energy policy approaches marginalizing local 
manufacturers of renewable energy systems. This was indeed the case of Peru's town of Arequipa where some 55,000 of 200,000 households are equipped with solar water heaters manufactured in the city since the 1930s, whose local manufacturers were indeed marginalized by the introduction of quality certifications and efficiency thresholds [31].

Second, aware of the exceptionally rapid pace of today's innovation in new energy technology and of its profound social and economic impacts, policy makers should seek the advice of energy managers trained to the aforementioned systems view of energy via courses and professional practice encompassing technology, economics and management [32].

Third, to reach out the community policy makers will develop effective, and thus cultural-driven, communication activities built around what matters most to the community to be engaged. It may not be surprising, in this respect, to learn that adopters of solar energy in Wisconsin share "an interest in technical innovation and enjoyment of the technical aspects of energy systems" [33]; whereas those in Ghana seek "autonomy in electricity supply via domestic solar systems" chiefly due to poor (inefficient and costly) centralised electricity provision [34].

Fourth, aware of the often inadequate state of education in solar energy in many countries [35], policy makers are recommended to establish public renewable energy institutes charged with two tasks: $i$ ) to provide enhanced education including updated best practices and lessons learned from across the world [36], and ii) to articulate clear and effective transitions plans with targets, financial resources, and indicators necessary to achieve sound and realistic targets for distributed generation from renewable energy sources.

After emphasizing the "unbearable cost" of renewable energy for over two decades, now that the cost of generating electricity via photovoltaic solar modules has literally collapsed, the same critics point to the "unbearable cost" and lack of reliability posed by the intrinsic intermittency of energy obtained from sunlight, wind and water.

However, the Li-ion battery storage technology is experiencing the same cost reduction trend of silicon solar cells thanks to its mass scale and rapidly growing industrial uptake leading to fast reductions in process costs [37], first in China, South Korea and Japan, and now inevitably in all main industrial countries.

We have lately shown elsewhere how, thanks to solar energy coupled to the Li-ion battery and solar hydrogen storage technologies, not only families and companies but entire regions and islands can now safely rely on renewable energy to meet all their energy needs [38].

The transition from polluting, unevenly distributed and costly fossil fuels is no longer matter of environmental sustainability but rather of economic competitiveness and of short-term economic sustainability.
The aforementioned guidelines are provided to policy makers to involve citizens and civil society bodies in a socially and technically feasible effort whose environmental, health, social and economic benefits will ne shortly and lastly reflected in the daily life of their communities.

\section{Acknowledgments}

This article is dedicated to the memory of Father Bernard Verspieren (1924-2003) for all he did pioneering the use of photovoltaic energy to power water pumps in drought-affected Mali, saving human lives in Africa first and then in all developing countries who adopted Mali Aqua Viva's model.

\section{Author Information \\ ORCID}

Mario Pagliaro: 0000-0002-5096-329X

Francesco Meneguzzo: 0000-0002-5952-9166

\section{Notes}

The authors declare no competing financial interest.

[1] S. Sorrell, Jevons' Paradox revisited: The evidence for backfire from improved energy efficiency, Energy Policy, 2009, 37, 1456-1469.

[2] K. Turner, "Rebound" Effects from Increased Energy Efficiency: A Time to Pause and Reflect, Energy J. 2013, 34, 25-42.

[3] F. Meneguzzo, R. Ciriminna, L. Albanese, M. Pagliaro, The Great Solar Boom: A Global Perspective into the Far Reaching Impact of an Unexpected Energy Revolution, Energy Sci. Eng. 2015, 3, 499-509.

[4] R. Galvin, Energy poverty research: A perspective from the poverty side In Inequality and Energy, Academic Press, San Diego: 2020; pp. 221-248.

[5] M. Kumar, Non-universal nature of energy poverty: Energy services, assessment of needs and consumption evidences from rural Himachal Pradesh, Energy Policy 2020, 138, 111235.

[6] D. J. Murphy, The implications of the declining energy return on investment of oil production, Philos. Trans. R. Soc. A. 2014, 372, 20130126.

[7] F. Meneguzzo, R. Ciriminna, L. Albanese, M. Pagliaro, The energypopulation conundrum and its possible solution, arXiv 2016, 1610.07298.

[8] International Energy Agency, World Energy Balances 2019, Paris: 2019. See at the URL: www.iea.org/statistics/

[9] China Electricity Council, 29 January 2019. See at the URL: www.cec.org.cn/yaowenkuaidi/2019-01-29/188578.html

[10] L. Yuanyuan, The number of public charging stations for EVs in China surges 50.5\% in May, Renewable Energy World, 2 July 2019. See at the URL: www.renewableenergyworld.com/2019/07/02/the-number-ofpublic-charging-stations-for-evs-in-china-surges-505-in-may/\#gref.

[11] L. Myllyvirta, Guest post: Why China's $\mathrm{CO}_{2}$ emissions grew 4\% during first half of 2019, CarbonBrief, 5 September 2019. See at the URL: www.carbonbrief.org/guest-post-why-chinas-co2-emissions-grew-4during-first-half-of-2019

[12] Y. Zheng, S. Li, S. Xu, Transport oil product consumption and GHG emission reduction potential in China: An electric vehicle-based scenario analysis. PLOS ONE 2019, 14(9): e0222448.

[13] D. Maugouber, D. Doherty, 2019 Road Fuel Outlook, Bloomberg New Energy Finance, New York: 2019. See at the URL: https://about.bnef.com/blog/three-drivers-curbing-oil-demand-roadtransport/

[14] Benchmark Mineral Intelligence, The Three Tiers of Battery Megafactories, benchmarkminerals.com, 13 September 2019. See at the URL: www.benchmarkminerals.com/the-three-tiers-of-batterymegafactories. 
[15] Bloomberg New Energy Finance, Electric Vehicle Outlook 2018, New York: 2018.

[16] Bloomberg New Energy Finance, Electric Vehicle Outlook 2019, New York: 2019.

[17] L. Albanese, R. Ciriminna, F. Meneguzzo, M. Pagliaro, The Impact of Electric Vehicles on the Power Market, Energy Sci. Eng. 2015, 3, 300309.

[18] R. Ciriminna, L. Albanese, M. Pecoraino, F. Meneguzzo, M. Pagliaro, Solar Energy and New Energy Technologies for Mediterranean Countries, Global Chall. 2019, 3, 1900016.

[19] P. Sanjay, India Added 5.4 GW of Solar in 9M 2019, with $2.2 \mathrm{GW}$ Installed in Q3 2019, Mercom India, 21 November 2019. See at the URL: https://mercomindia.com/india-solar-installed-q3-2019.

[20] U.S. Commercial Service of the U.S. Department of Commerce, India energy, 2019. See at the URL: www.export.gov/article?id=India-Energy.

[21] Asian Development Bank, Rajasthan Renewable Energy Transmission Investment Program, Manila: 2019. See at the URL: www.adb.org/sites/default/files/project-documents/45224/45224-002dpta-en.pdf.

[22] S. Islam, Bangladesh considers funding for solar home system expansion, pv-magazine, 20 May 2019.

[23] a) official data as of 31 January 2020 available at: http://ajay.eeslindia.org/index.php; b) N. Kabeer, Cabinet Approves Program to Provide 300,000 Solar Street Lights Across India Northeastern states, districts affected with left-wing extremism, and areas devoid of grid connectivity are the focus of the program, Mercom India, 7 June 2018.

[24] S. Akram, Africa embraces an $\$ 8$ billion solar market for going off-grid, Ozy, 4 February 2019. See at the URL: www.ozy.com/fastforward/africa-embraces-an-8-billion-solar-market-for-going-offgrid/92303.

[25] M-Kopa Solar, Pricing for M-Kopa 6 Device, 2020. See at the URL: www.m-kopa.com/products.

[26] J. Lee, M. McCuskey Shepley, Benefits of solar photovoltaic systems for low-income families in social housing of Korea: Renewable energy applications as solutions to energy poverty, J. Build. Eng. 2020, 28, 101016.

[27] LG Electronics, Module LG370Q1C-V5. See at the URL: www.lg.com/us/business/solar-panels/lg-lg370q1c-v5

[28] Z. Liu, D. Wu, B.-J. He, Y. Liu, X. Zhang, H. Yu, G. Jin, Using solar house to alleviate energy poverty of rural Qinghai-Tibet region, China: A case study of a novel hybrid heating system, Energ. Buildings 2018 , 178, 294-303.

[29] K. E. Kanyarusoke, Solarising tropical Africa's rural homes to sustainably overcome energy poverty, IOP Conf. Ser.: Earth Environ. Sci. 2017, 93, 012047

[30] C. M. Luo, Introduction: A Crisis Decade for the EU, In The EU's Crisis Decade, Palgrave Macmillan, Singapore: 2020; pp.1-5.

[31] A. Israel, M. Jehling, Using solar house to alleviate energy poverty of rural Qinghai-Tibet region, China: A case study of a novel hybrid heating system, Energy Policy 2019, 133, 110905.

[32] R. Ciriminna, M. Pecoraino, F. Meneguzzo, M. Pagliaro, Reshaping the education of Energy managers, Energy Res. Soc. Sci. 2016, 21, 44-48.

[33] C. Schelly, Residential solar electricity adoption: What motivates, and what matters? A case study of early adopters, Energy Res. Soc. Sci. 2014, 2, 183-191.

[34] F. Boamah, E. Rothfuß, From technical innovations towards socia practices and socio-technical transition? Re-thinking the transition to decentralised solar PV electrification in Africa, Energy Res. Soc. Sci. 2018, 42, 1-10.

[35] T. C. Kandpal, L. Broman, Renewable energy education: a global status review, Renew. Sustain. Energy Rev. 2014, 34, 300-324

[36] R. Ciriminna, F. Meneguzzo, M. Pecoraino, M. Pagliaro, Rethinking Solar Energy Education on the Dawn of the Solar Economy, Renew. Sustain. Energy Rev. 2016, 63, 13-18.
[37] M. Wentker, M. Greenwood, J. Leker, A Bottom-Up Approach to Lithium-Ion Battery Cost Modeling with a Focus on Cathode Active Materials, Energies 2019, 12, 504.

[38] M. Pagliaro, Renewable energy systems: Enhanced resilience, lower costs, Energy Technol. 2019, 7, 1900791. 


\section{Distributed Generation from Renewable Energy Sources: Ending Energy Poverty Across the World M. Pagliaro, F. Meneguzzo}

Following an updated outlook of global energy production and utilization, we show through selected examples from both developing and developed countries how distributed generation from renewable energy sources, and from solar energy in particular, is the key solution to ending energy poverty across the world. Guidelines aimed at policy makers suggest a systems view of energy that will be instrumental in guiding the transition from fossil fuels to combustion-free renewable energy for all energy end uses.

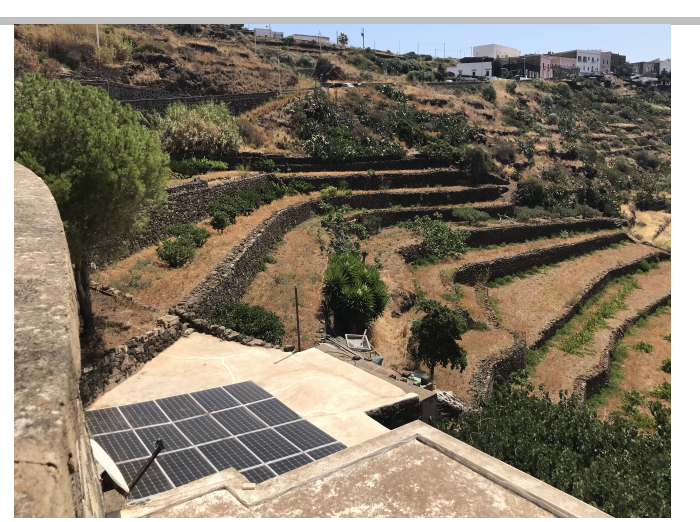

